Behavioural Science | Dr Eriko Teramura

\section{The effects of workplace norms on women's work behaviour in Japan}

\begin{tabular}{|c|c|c|}
\hline $\begin{array}{l}\text { Professor Eriko Teramura } \\
\text { from the Meikai University } \\
\text { Faculty of Economics is a } \\
\text { Japanese social scientist who } \\
\text { specialises in human resource } \\
\text { management and gender } \\
\text { theory. Her current research } \\
\text { centres around the workplace } \\
\text { culture of Japan and the } \\
\text { practices specific to Japanese } \\
\text { companies that may be } \\
\text { affecting the employment of } \\
\text { women and their decisions to } \\
\text { start a family. Using empirical } \\
\text { analysis, Professor Teramura } \\
\text { examines the relationship } \\
\text { between workplace norms } \\
\text { and women's choices } \\
\text { concerning their employment } \\
\text { and family formation. }\end{array}$ & $\begin{array}{l}\text { t present, and in recent years, } \\
\text { women's labour participation } \\
\text { rates have been low in Japan. } \\
\text { Over a quarter of a century has passed } \\
\text { since the Equal Employment Opportunity } \\
\text { Law of } 1986 \text { was put in place. Although } \\
\text { there has been a tendency to continue } \\
\text { working after childbirth since 2010, many } \\
\text { aspects of the gendered employment } \\
\text { structure hasn't changed. } \\
\text { In her recent research at Meikai } \\
\text { University, Professor Teramura seeks to } \\
\text { assess how use of the childcare leave } \\
\text { system has changed between } 2002 \text { and } \\
\text { 2011, and what insight it can give into } \\
\text { workplace cultures and their effect on } \\
\text { female labour statistics. The research } \\
\text { carried out by Professor Teramura and } \\
\text { her collaborators finds that the social } \\
\text { norms that Japanese culture is familiar } \\
\text { with may still be influencing women's } \\
\text { work behaviour and family formation } \\
\text { informally. Although measures may } \\
\text { be in place to aid the continuation } \\
\text { of work for women, "business } \\
\text { norms" in a company may influence } \\
\text { women's work choices and } \\
\text { birth behaviours. } \\
\text { THE CHALLENGE OF A } \\
\text { GLOBALLY UNEOUALLED } \\
\text { DECLINING BIRTRATE } \\
\text { Women's labour participation rates } \\
\text { have been low in Japan for many years, } \\
\text { which has put pressure on the economy. } \\
\text { Japan has an ageing population with } \\
\text { a smaller economic class than most } \\
\text { of the world, which adds strain to } \\
\text { their economy in the long-term. } \\
\text { With a globally unequalled } \\
\text { declining birthrate and } \\
\text { a society that needs } \\
\text { more economically } \\
\text { active members, the } \\
\text { government is trying to } \\
\text { encourage more people }\end{array}$ & $\begin{array}{l}\text { to work. They are doing everything they } \\
\text { can to encourage women to continue } \\
\text { working after marriage and childbirth. } \\
\text { Professor Teramura's research assesses } \\
\text { these measures and in particular, the } \\
\text { childcare leave system. In Japan, women } \\
\text { may take childcare leave until their } \\
\text { child is one year old, but this can be } \\
\text { extended twice if the child does not } \\
\text { attend nursery, and can be taken until the } \\
\text { oldest child is two years old. Compared } \\
\text { to other countries, this is a long leave } \\
\text { period. In addition, the contents of the } \\
\text { coexistence support system are not } \\
\text { limited to the childcare leave system, but } \\
\text { also include a short-term work system, } \\
\text { and a child's nursing leave system. } \\
\text { However, despite these measures, } \\
\text { there has been no significant increase in } \\
\text { employment rates, with rates at } 35.8 \% \\
\text { to } 37.6 \% \text { from } 2003 \text { to } 2009, \text { respectively. } \\
\text { Despite the introduction of a coexistent } \\
\text { support system and continued } \\
\text { employment, the majority of women } \\
\text { are still leaving their jobs at birth and are } \\
\text { marrying later or remaining unmarried. } \\
\text { WHY IS woMEN'S PARTICIPATION } \\
\text { IN LABOUR NOT PROGRESSING } \\
\text { IN JAPAN? } \\
\text { Clearly, although measures are in place } \\
\text { to aid the re-employment of women } \\
\text { in Japan, they are not promoting any } \\
\text { significant change in gender equality } \\
\text { (wage gap, promotion and so on). } \\
\text { The reason for this, Professor Teramura } \\
\text { speculates, is that workplace norms } \\
\text { and atmospheres are affecting their } \\
\text { employment. Analysis was carried } \\
\text { out that looked into a company's } \\
\text { "compatibility support system"and } \\
\text { "atmosphere of using (system) use } \\
\text { (work code)" to look at whether } \\
\text { these had an effect on women's work } \\
\text { habits. Business norms proved very } \\
\text { important when considering the labour }\end{array}$ \\
\hline
\end{tabular}

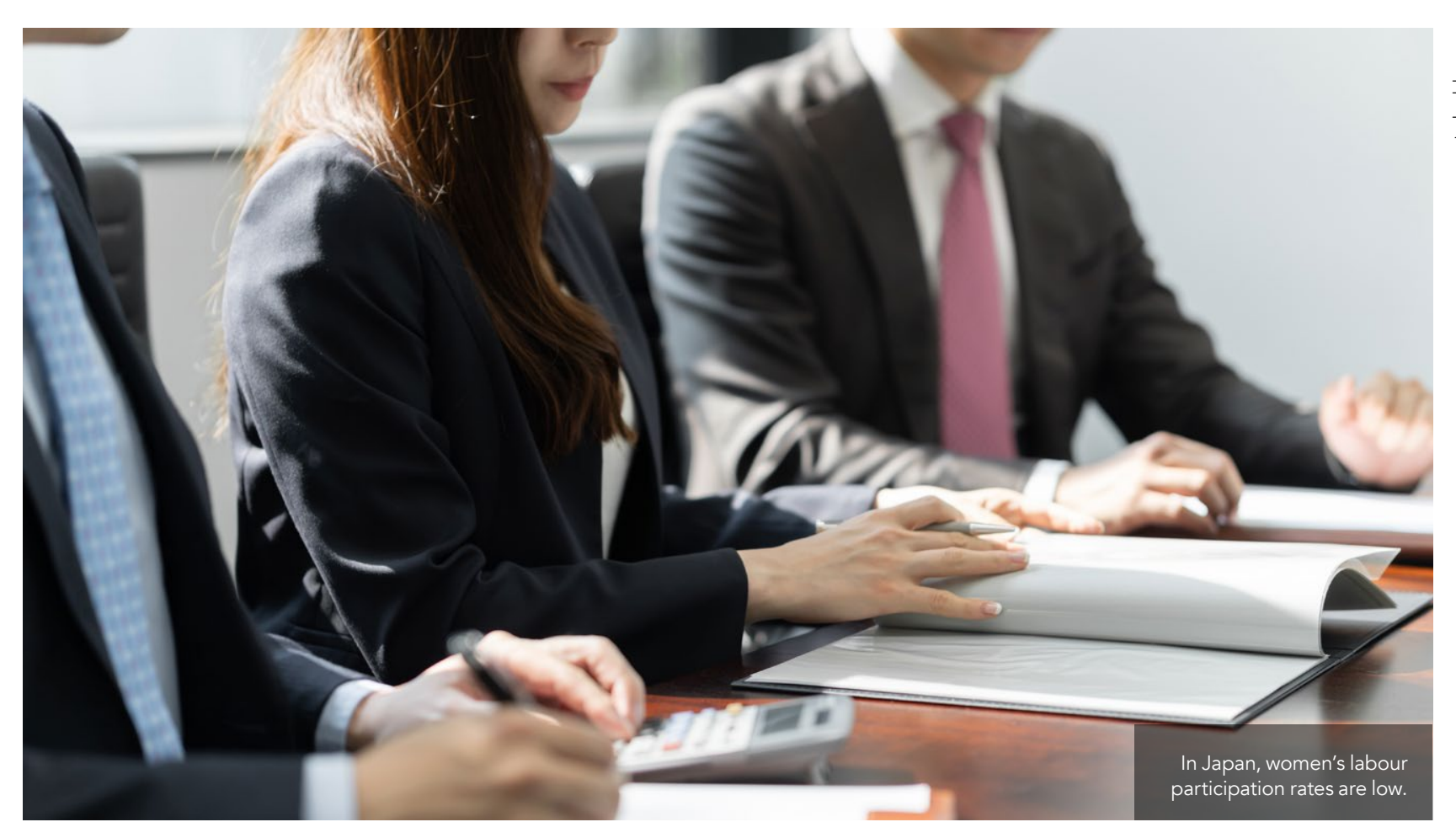

participation rates, and her research showed that positive norms encouraged women to return to work.

A quick note on what Professor Teramura means by business norms: her work cites Akerlof and Kranton (2002: 2010) who believe that the norms of how people act depends on their position in the social context. Psychologists say that people can internalise social norms because they become their own and then guide their behaviour. Norm can be taught by parents, teachers, priests, etc, as well as workplace culture,

Business norms specifically refer to the ways in which people are expected (n) thvironment based on projected ideals Teramura uses the example of people in the workplace thinking that "women should quit their job following marriage and childbirth." This then promotes the dea that it is desirable for a woman to act on these business norms, which can influence behaviour.

Using research from Fortin (2005), Teramura's studies examine the causal relationship between gender division secifically focusing on the busiss no pecicall focring on he business nom
Although measures are in place to aid the re-employment of women in Japan, they are not promoting any significant change in gender equallity.

stay at home and men should be the main THE CHILDCARE LEAVE SYSTEM earners. Her work also cites Bertrand, Pan ALONE ISN'T ENOUGH TO AFFECT and Kamenica (2013), looking at the role WOMEN'S WORK of male earners and the social norms that Professor Teramura's research used suggest that women shouldn't earn more panel data of public statistics to examine than men. All of the above are examples the relationship between workplace norm woms that afect the way in which women perceive work, and their position employment and birth behaviour through

Figure 1: Employment rate of women when their first child is one year old

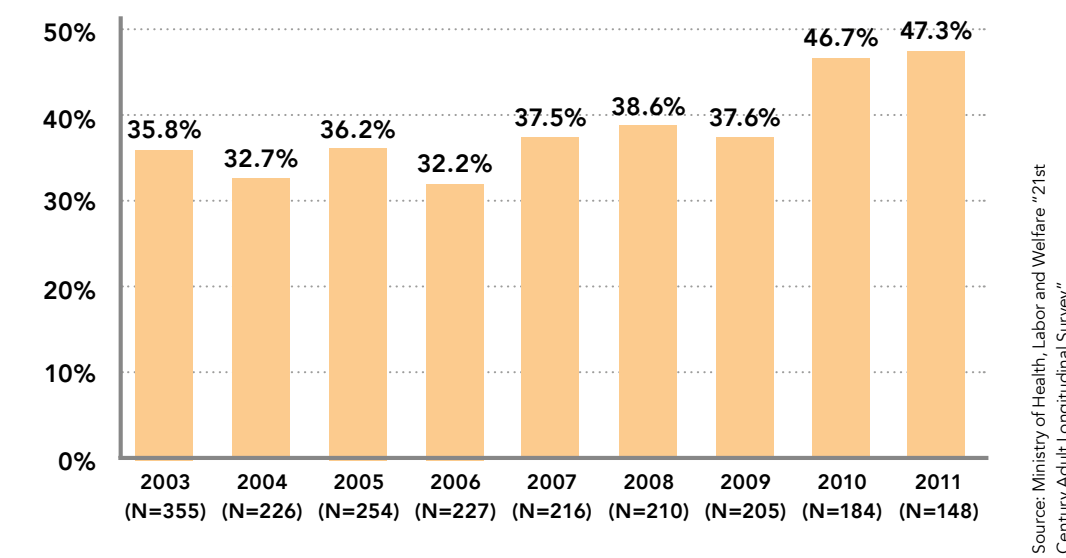

The employment rate for women at the point at which
since 2010, but the ratio is still approximately half. 
Figure 2: Proportion of individuals using the compatibility support system (by year, \%)

Child Care Leave System

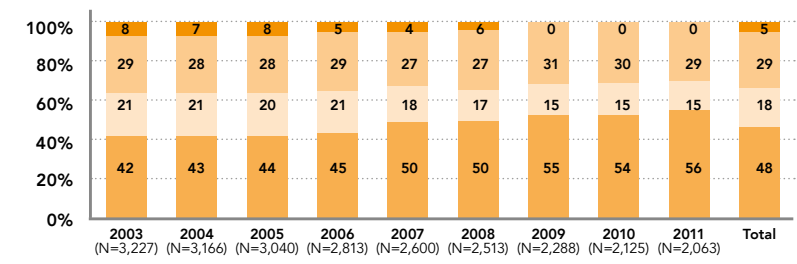

Short-Time Work System

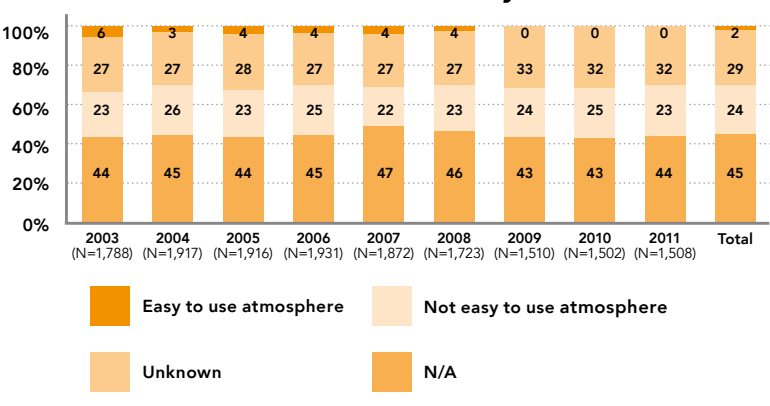

Care Leave System

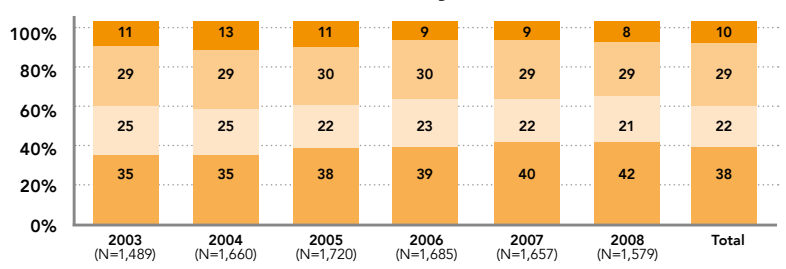

Professor Teramura"s work suggests that "social norms" in Japanese society may still influence women's work behaviour and family

formation informally.

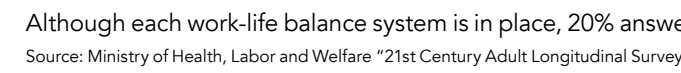

having a "compatibility support system"and In fact, the research showed that "atmosphere of using the system" business norms have a huge effect impacted women's willingness to work. on female birth behaviour in general. The existence of the system and its As a result of the analysis, it became practical use in the workplace had apparent that the childcare leave system a positive effect on birth behaviour. alone is not enough to have an effect on Although it was demonstrated that women's work. Although the childcare leave the influence of a "system-friendly system is easy to use, it depends on the atmosphere" is small when it comes attitude and norms of the employer as to to the improvement in women's work whether it is a success. Her research found in Japan, the research suggests that that when the norm such as a "friendly the "system-friendly atmosphere" atmosphere is encouraged alongside the may have further influence on fem $\begin{array}{ll}\text { government initiative it had a positive effect } & \text { birth behaviour in the medium } \\ \text { on motivation. } & \text { and long term. }\end{array}$

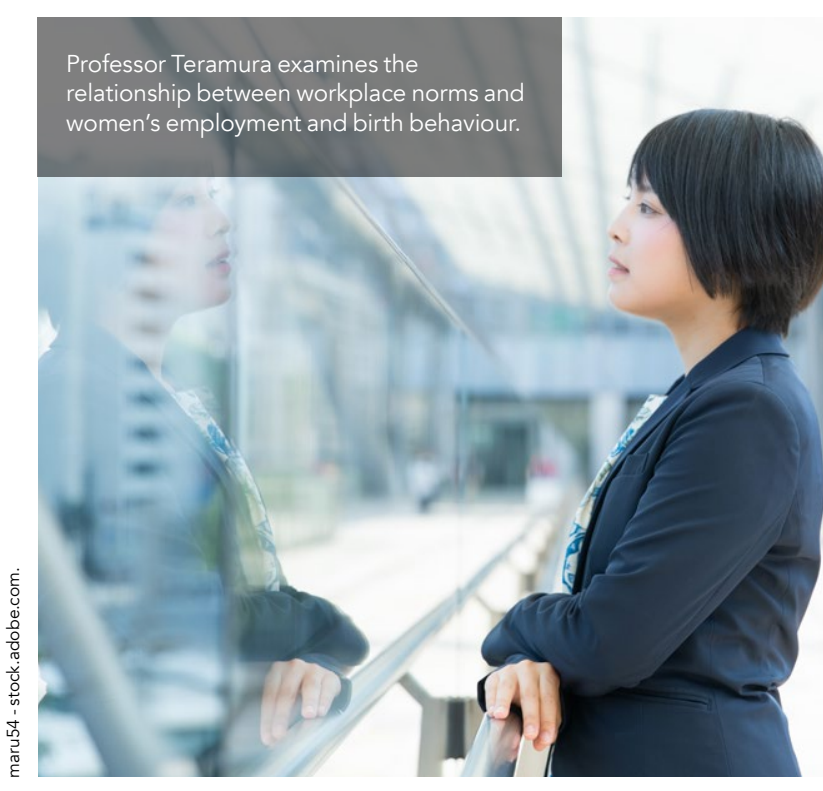

\section{TAIWAN VS JAPAN}

In order to further characterise Japanese work culture, Professor Teramura's research was clarfied in a comparative study with Taiwan - a country also experiencing found that the happiness level of women decreased especially after birth both in Japan and Taiwan. In addition, the study showed that Japanese women felt inform pressure in the workplace compared to Taiwanese women. The norms that they were exposed to made Japanese working women more aware of their surroundings and had even led to women leaving work

\section{CONCLUSION}

Professor Teramura's work suggests that "social norms" in Japanese society may and family formation informally. It may be influenced by the social background unique to Japanese society and social norms that value individuals to "go with the flow" Whilst it is important to note that only some women (e.g. those working for large companies and in full-time employment), are easily accessible and accounted for in the studies, it's still true that the influence of workplace norms have significant effects on work retention motivation. The parental leave system and its ease of use clearly has working after childbirth.

Behind the Research

\section{Dr Eriko Teramura} E: eriko@meikai.ac.jp T: + 81 47-355-5111 W: Wttp://www.meikai.ac.jp/english/index.html
W: https:///rikoteramura.amebaownd.com

\section{Research Objectives}

Professor Eriko Teramura's research focuses on human resource management and gender theory.

\section{Detail}

1 Akemi, Urayasu-shi,Chiba, Japan, 279-8550

Bio

Eriko Teramura is a Professor of Meikai University, Faculty of Economics in Japan. A Japanese social scientist gender theory. She studies women's labour issues, and is particularly interested in the influence that normative awareness in the workplace has on workers' work behaviour. Prof Teramura is also interested in women's turnover and reemployment behaviour.

\section{Funding}

This study is part of the research results of the Japan Society for the Promotion of Science Grant-in-Aid for Scientific Research (Foundation (C) Subject Number: 15K01937) and Foundation (B) Subject Number: 17KTO037.

\section{Collaborators}

- Kung Hsiang-Ming (Shih Hsin University, Taiwan) Risa Hagiwara (Meikai University, Japan)

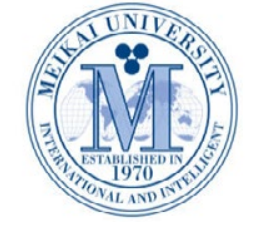

\section{明海大学 MEIKAI UNIVERSITY}

\section{References}

Teramura, E. (2019). The Effects of Workplace Norms on Female Labour Supply and Childbirith in Japan. 2014 Labour and Employment Relations Association /Allied Social Sciences
Association Annual Meeting / Meikai Economics Discussion Association Annual Meeting
Paper 19-001 [05/08/2019]

Teramura E. and Hagiwara R. (2019). The Effect of Family and Income on Happiness: Evidence from Japan and Taiwan. 2019 Population Association of Taiwan Annual Conference
Economics Discussion Paper 19-002. [05/08/2019]

Teramura E. and Hsiang-Ming K. (2017). Labour and Family of High Educational Women Using EASS and In-depth Interview Comparative Analysis of Taiwan and Japan. 2017 Japanese

Teramura, E. (2013). Effects of "Workplace Norms" on Female Turnover in Japan: In-depth Interviews with Female Workers.
Journal of Gender Studies, Ochanomizu University. (16), $37-57$ (in Japanese)

Bertrand Marianne, Pan Jessica and Kamenica Emir (2013). Gender identity and relative income within households. NBER Working Paper Series, National Bureau of Econs
Working Paper 19023. Doi: 10.3386/w19023

Fortin, M.N. (2005). Gender role attitudes and the Labour-market Economic Policy. 21:3.416-38. Doi. 10.1093/oxrep/grio24

Akerlof, G.A., and Kranton,R.E. (2002). Identity and Schooling: Some Lessons for the Economics XL:1167-1201 https:///pdfs.semanticscholar. org/3fb6/057c7f05457ee78437fbef1f5af1eb8f8773.pdf Akerlof, G.A., and Kranton, R.E. (2010). Identity Economics: Princeton University Press. http:///www.sfu.ca/ c cbidner/files/ Bidner_BookReview AK2010.pdf

\section{Personal Response}

\section{What is next for your research?}

II This "atmosphere" variable requires an interdisciplinary approach, so I would like to pay attention not only to economics but also to management and sociology. I would like to elucidate why such behaviour of female. workers occurs in Japanese corporate organisations. 